\title{
46. マウストリソミー 16 の実験的研究
}

一七ト染色体異常, とくにトリソミー 21 の動物モデルとして—

\author{
宮 原 晋 一 \\ 佐賀医科大学 病理
}

マウス染色体 No. 16 は，ヒ卜染色体 No. 21 と三 つの共通する遗伝子座, superoxide dismutase-1, interferon receptor protein および phosphoribosylglycinamide synthetase, を有することから，マウス トリソミー 16 (Ts 16) はヒトトリソミー21 の動物 モデルとなることが予想されていだ．

2 個の転座染色体の各 1 本ずつの腕が相同の染色体 No. 16 となっている Rb(16.17) Bnr/Rb(9.16)9Rma 雄と，正常 NMRI 倠マウスの交配によって生しる Ts 16 胎仔を観察した. その結果, 共通房室管遣残（心 内膜床欠損)，全身の浮重および尿管水腫・水堅症が見 いだされた.これらの異常がいずれるヒトトリンミー 21 に報告されていることから，形態学的にマウス Ts 16 がヒトトリソミー 21 の動物モデルとなりらること が示唆された2).

そこで今回は inbred の雙マウスを交配に用い，生 しる Ts 16 胎仔の頻度, 肉眼的異常を調へ，とくに 共通房室管遺残の成立ち方を明らかにして，それぞれ ヒトトリソミー21で報告されている事実と比較した。

材料および方法

$\mathrm{Rb7Bnr} / \mathrm{Rb} 9 \mathrm{Rma}$ 雄と C57BL/6 の倠が実験に用 いられた．心奇形の成立ち方の解明には， $\mathrm{Rb}(9.16) 9$ $\mathrm{Rma} / \mathrm{Rb}(16.17) 32 \mathrm{Lub}$ 雄を用いた. 胵栓発見日を 妊娠 1 日目とした。屠殺 2 時間前に妊娠倠マウス腹腔 内にコルセミドを投与した．染色体の分析には胎跉 12 15 日は胎膜を，16 日以降は細切した肝組織を用 い, 直接法で行った.

\section{结果および考実}

Ts 16 胎仔の全生存胎仔中に占める割合は，胎踰 12 日の $24.2 \%$ から 20 日の $6.7 \%$ と減少㑯向を示した. 経日的な減少傾向は明らかではなかったが，次のよう な事実により Ts 16 胎仔が選択的に死亡することが 示唆された. すなわち，胎齢 12 日から 14 日までの 間, Ts 16 胎仔の中に著明な発育不全を示するのが約 $1 / 4$ みられ，死亡しつつあるすのと考えられた．胎蛉 15 日以降の死亡胎仔の多くが後に述べる Ts 16 と同 様の形態異常を示しており，Ts 16 胎仔であることが 疑われた．前者はヒト染色体異常肧でみられる初期流
産例に，また後者はそれ以降の死亡例に相当すると考 えられた。

眙龄 14 日から Ts 16 胎仔の項部に始まる浮隀は 全身性となり，胎侴 16 日に最も高度となり，18 日以 降その程度を減した，胎峆 17 日以降には尿管水腫お よび水堅症が発生した，以上の上らな異常はトリソミ 一 21 を含むとト染色体異常胎児に，ときに合併する ことが報告されている.

胎龆 15 日以降に実体影敨鏡下に解剖された Ts 16 胎仔 22 例中, 21 例に共通房室管遺残（完全型）が見 いだされた．また，円錐・動脈幹部では両大血管右室 起始症 14 例，および動脈幹遗残症 8 例が見いだされ た3).

そこで共通房室管遺残の成立ち方を明らかにするた

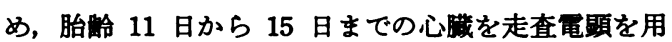
いて钼察した. Ts 16 胎仔心は正常心に比へて発育遅 延を示し, 房室孔の左心室から右心室への伸展か阻害 され，その右側端が久損を生じる心室中隔にかかる程 度であった. また，前後の房室部心内膜床はまったく 慗合しなかった．心房では一次中隔がその上端で痕跡 的に形成されるのみで，心房中隔は大部分が久損して いた. ヒトトリソミー 21 では, 共通房室管は両心室 に開孔するすのが大多数であり()，マウス Ts 16 心で みられた，より初期心の状態で発育が停止した結果生 した primitive type ともいらべきすのはきわめて少

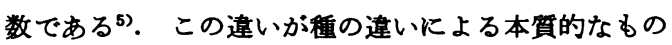
か, あるいは観宗時期の差等による本奇形の spectrum をみているるのか, 現在検討中である.

\section{文献}

1) Gropp, A. : Virchows Arch. Pathol. Anat., 395, 117 (1982)

2) Miyabara, S., Gropp, A. and Winking, H. : Teratology, 25, 369 (1982)

3) Miyabara, S., Sugihara, H., Yonemitsu, N. and Yun, K. : Cong. Anom., 24, 283 (1984)

4) Bharati, S. and Lev, M. : Am. Heart J., 86, 553 (1973)

5) Hutchins, G.M., Liebman, L., Moore, W. and Gharagozloo, F. : Am. J. Pathol., 95, 579 (1979) 